\title{
The Implications of Unveiling Cultural Hegemony Portrayed in a Pre-Intermediate Textbook for EFL Learning and Teaching ${ }^{1}$
}

\author{
Diana Andrea Caro Romero \\ diana.a.c.238@hotmail.com \\ Héctor Javier Caro Romero \\ lenguasdefuego@outlook.com
}

Cultural hegemony is understood as the practice of promoting and imposing a culture. Usually the culture imposed is from a politically powerful nation over a subordinate one (Fairclough, 2003). We became interested in understanding the discourse found within EFL textbooks that could be promoting cultural hegemony. Using these textbooks could have profound implications on language learning and teaching. This is not just a matter of using American or British English in an EFL textbook; rather, it is necessary to understand the intentions of the authors of these books. It could be that the purpose is to promote one culture, possibly their own culture, as the best one or the one to follow.

When a publishing house launches a new textbook, they want their book to be used as many institutions as possible. In this case, the authors do their best to fit a wide-ranging audience, as well as make the textbooks useful for EFL teachers and learners. However, we have come to realize an important aspect about textbooks that we might overlook. During our time in the master's program, we have had the opportunity to analyze textbooks, which often times can be used to communicate ideologies, reduce cultural diversity, and disempower teachers and learners.

\footnotetext{
${ }^{1}$ Reflective essay.
} 


\section{ENLETAULA Doumbal}

For this essay, we looked at a pre-intermediate EFL textbook commonly used to teach English to undergraduate students in Colombia. In the textbook, we analyzed two lesson framed under the title "World Culture". The textbook was written by British authors, and it was apparent that the British culture was set as an example to follow. Clarke and Clarke (1990) suggested that there is stereotyping and bias when it comes to British EFL materials in terms of gender, race, class, religion, and other aspects of culture. When one culture is imposed over another, then it becomes the example of what others should be, believe, and want to be part of in a globalized world. As one of the lessons suggested, if you want to be cool, you have to place your eyes on London's culture.

Apart from presenting bias for one culture over the other, there seemed to be a reduction of cultural diversity, such as ways of being and believing. Just in the title, "World Culture", we noticed that the authors neglected in recognizing other cultures. Fairclough (2003) stated that "achieving hegemony entails achieving a measure of success in projecting certain particulars as universals" (p. 31), and this was apparent in the pre-intermediate textbook.

As part of a larger research project, it has become necessary to unveil the cultural hegemonic aspects in EFL textbooks in order to raise cultural awareness about the "intentions" behind these discourses (Van Dijk, 2000). As teachers, we are responsible for promoting critical thinking in the classroom. Because of this, we need to take on a critical position when using EFL textbooks and materials that may be promoting hegemonies.

As a way to conclude this reflection, we can say that even though cultural hegemony was portrayed in this textbook, teachers can take advantage of the material to promote critical thinking skills. Since this book is also used to teach undergraduate language majors, it is crucial for them as future language teachers to become aware of cultural hegemony in the material they use. Likewise, we can help our students explore the idea that even when certain cultures are displayed as being "great, we also have a culture that is diverse and makes us believe, do, and be who we are. Finally, we consider that it is relevant that teachers share with their students that it is okay to learn about others and understand both the superficial and deep culture. Cultures are different, and those differences do not make one culture better or worse than another. We are just different. 


\section{References}

Clarke, J., \& Clarke, M. (1990). Stereotyping in TESOL materials. In B. Harrinson (Ed.). Culture and the language classroom. Hong Kong: Modern English Publication and the British Council.

Fairclough, N. (2003). Analysing discourse: Textual analysis for social research. London, UK: Routledge.

Van Dijk, T. A. (2000). Ideology and discourse: A multidisciplinary introduction. Barcelona; Pompeu Fabra University.

\section{How to cite this essay:}

Caro, D. A., \& Caro, H. J. (2019). The implications of unveiling cultural hegemony portrayed in a pre-intermediate textbook for EFL learning and teaching. Enletawa Journal, 12(1), 8789.

\section{About the authors:}

Diana Andrea Caro Romero is a Master's in Language Teaching students at the Universidad Pedagógica y Tecnológica de Colombia (UPTC). She holds a B.A. in Modern Languages from the UPTC. Diana is an English teacher at Colegio Cristiano Filadelfia, Tunja, Colombia.

Héctor Javier Caro Romero is a Master's in Language Teaching student at the Universidad Pedagógica y Tecnológica de Colombia (UPTC). He holds a B.A. in Modern Languages from the UPTC. Héctor is an English teacher at the Universidad Pedagógica y Tecnológica de Colombia, Tunja, Colombia. 